\title{
Factors associated with the maintenance of exclusive breastfeeding in the late postpartum
}

\author{
Fatores associados à manutenção do aleitamento materno exclusivo no pós-parto tardio \\ Factores asociados al mantenimiento de la lactancia exclusiva en el posparto tardío
}

\author{
Vanessa Aparecida Gasparin ${ }^{a}$ \\ Juliana Karine Rodrigues Strada ${ }^{b}$ \\ Bruna Alibio Moraes ${ }^{c}$ \\ Thaís Betti ${ }^{b}$ \\ Érica de Brito Pitilin ${ }^{d}$ \\ Lilian Cordova do Espírito Santo
}

\begin{abstract}
How to cite this article: Gasparin VA, Strada JKR, Moraes BA, Betti T, Pitilin EB, Espírito Santo LC. Factors associated with the maintenance of exclusive breastfeeding in the late postpartum. Rev Gaúcha Enferm. 2020;41(esp):e20190060 doi: https://doi.org/10.1590/19831447.2020.20190060
\end{abstract}

a Universidade do Estado de Santa Catarina (UDESC) Departamento de Enfermagem. Chapecó, Santa Catarina, Brasil.

- Universidade Federal do Rio Grande do Sul (UFRGS), Escola de Enfermagem, Programa de Pós-Graduação em Enfermagem. Porto Alegre, Rio Grande do Sul, Brasil.

Pesquisador autônomo. Porto Alegre, Rio Grande do Sul, Brasil.

${ }^{d}$ Universidade Federal da Fronteira Sul (UFFS), Departamento de Enfermagem. Chapecó, Santa Catarina, Brasil.

' Universidade Federal do Rio Grande do Sul (UFRGS), Escola de Enfermagem, Departamento de Enfermagem Materno-Infantil. Porto Alegre, Rio Grande do Sul, Brasil.

\section{ABSTRACT}

Objective: To identify the factors associated with the maintenance of exclusive breastfeeding and to verify the justification for the introduction of other liquids in the late postpartum of mothers and children attended by a breastfeeding consultant.

Method: A non-comparative prospective cohort, conducted with 150 mothers and children. Data was collected at rooming-in 15 and 30 days after birth and analyzed by univariate analysis and multivariate regression.

Results: The reasons for introducing water, tea, and breast milk substitutes were the following: thirst, abdominal cramps, and infant crying, respectively. Vaginal delivery, not using a pacifier or bottle and seeking professional help after discharge were associated with the exclusivity of late postpartum breastfeeding.

Conclusion: The introduction of a professional breastfeeding consultant is of significant importance in the rise of exclusive breastfeeding rates.

Keywords: Breast feeding. Maternal-child nursing. Consultants. Postpartum period.

\section{RESUMO}

Objetivo: Identificar os fatores associados a manutenção do aleitamento materno exclusivo e verificar a justificativa para introdução de outros líquidos no pós-parto tardio, de mães e crianças atendidas por consultor em aleitamento materno.

Método: Coorte prospectiva não comparada, realizado com 150 com mães e crianças. Os dados foram coletados no alojamento conjunto, aos 15 e 30 dias após o nascimento e analisados por meio de análise univariada e regressão multivariada.

Resultados: Os motivos para a introdução de água, chá, e substitutos do leite materno foram respectivamente: sede, cólicas abdominais e choro da criança. 0 parto vaginal, a não utilização de chupeta ou mamadeira e a busca por ajuda profissional após a alta se associaram a exclusividade da amamentação no pós-parto tardio.

Conclusão: A inserção de um profissional consultor em aleitamento materno tem relevante importância na ascensão das taxas de aleitamento materno exclusivo.

Palavras-chave: Aleitamento materno. Enfermagem materno-infantil. Consultores. Período pós-parto.

\section{RESUMEN}

Objetivo: Identificar los factores asociados con el mantenimiento de la lactancia materna exclusiva y verificar la justificación para la introducción de otros líquidos en el posparto tardío de madres y niños atendidos por un consultor en lactancia materna.

Método: Cohorte prospectiva no comparativa realizada con 150 madres y niños. Los datos se recolectaron en el alojamiento conjunto 15 y 30 días después del nacimiento y se analizaron mediante análisis univariado y regresión multivariada.

Resultados: Las razones para introducir agua, té y sustitutos de la leche materna fueron las siguientes: sed, calambres abdominales y llanto infantil, respectivamente. El parto vaginal, no usar un chupete o biberón y buscar ayuda profesional después del alta se asociaron con la exclusividad de la lactancia durante el posparto tardío.

Conclusión: La incorporación de un consultor profesional en lactancia materna es de suma importancia en el aumento de las tasas de lactancia materna exclusiva.

Palabras clave: Lactancia materna. Enfermería materno-infantil. Consultores. Periodo posparto. 


\section{IINTRODUCTION}

The practice of breastfeeding has suffered various social and cultural influences due to the times and customs of each historical moment; however, the concrete establishment of its benefits has been found in scientific circles for over 50 years $(1)$

Although the privileges associated with breastfeeding are unquestionable, whether for the nursing mother or infant(2), its interruption before the recommended period is still frequent. In view of this, the qualification to act in face of this demand is necessary and rising, as the Lactation Consultant(3) professional.

Created in the 1980s, to receive the title of Lactation Consultant, the professional must be accredited by the International Board of Certified Lactation Consultants (IBCLC), the only internationally recognized professional lactation certification body to provide safe and evidence-based care for breastfeeding women and their babies(3).

Studies in Italy and the Netherlands, as well as a systematic review and meta-analysis, have already shown the superiority of a consultant's role in improving breastfeeding outcomes(4-6).

Based on the prerogatives of benefits combined with the performance of this professional, this study assumes that the performance of breastfeeding (BF) consultants in the immediate postpartum favors the establishment, as well as the exclusivity, of breastfeeding after discharge in the late postpartum, the most vulnerable phase due to insecurity and lack of knowledge in the management of the difficulties related to lactation(7).

This study aims to identify the factors associated with the maintenance of exclusive breastfeeding (EBF) and to verify the justification for the introduction of other liquids in the late postpartum of mothers and children attended by BF consultant.

\section{METHOD}

This study is part of the project entitled: "Breastfeeding Patterns of Children Attended by a Breastfeeding Advisory Team". The data used came from the follow-up of the participants during the 30 days postpartum.

This is a non-comparative prospective cohort study, conducted with mothers and children in the immediate postpartum period, hospitalized in a rooming-in modality and attended by a BF consultant at the Hospital de Clinicas de Porto Alegre/RS.

The institution's BF consultancy team consists of a nutritionist and two nurses, one of whom is accredited by the
IBCLC. The consultations are directed to cases in which difficulties in the effective establishment of breastfeeding are observed, which may become a barrier to the permanence of EBF.

Mothers and children in a rooming-in modality who had been assisted by a BF consultant residing in Porto Alegre or in the metropolitan region, who provided their telephone number, with full-term children (Capurro $\geq 37$ weeks) with a birth weight $\geq 2,500 \mathrm{~g}$ were included. Mothers with twin children who had a permanent or temporary indication for breastfeeding or who had to be separated after starting breastfeeding were excluded.

The period of inclusion of participants was August 2016 to January 2017, with follow-up by telephone until March of the respective year. Information was collected for this research in three moments: in person at the Obstetric Inpatient Unit (OIU), the woman being interviewed after the first 24 hours of the child's birth and after receiving care from a BF consultant, and by telephone 15 and 30 days after birth, with a maximum period for the application of the questionnaire of two days after the child reaches the established age for follow-up. For data collection two questionnaires were used, previously elaborated by the researchers and submitted to a pilot test. The first questionnaire, completed in person at the bedside in the OIU, contained sociodemographic and maternal variables related to current pregnancy, prenatal care and type of delivery. The questionnaire applied 15 and 30 days after birth, via telephone contact, addressed issues related to maternal habits, problems with breastfeeding and liquid introduction to the child.

The minimum sample size calculated was 150 individuals, using the WinPEPI software, version 11.43. A mean percentage of $60 \%$ (8) of EBF was considered at the end of the first month and a minimum risk rate of 1.48(9), with a power of $80 \%$, significance level of $5 \%$ and estimated loss of $20 \%$ over the follow-up.

The collected data was tabulated and evaluated by pairs to correct any typing errors and then analyzed in the SPSS (Statistical Package for the Social Sciences) statistical software, version 20.0. First, descriptive statistics were performed for the numerical variables through measures of central tendency and for those of categorical nature proportions.

The statistical calculation performed to test the differences between the before and the after measurements was the McNemar's test (non-parametric). To study the association between the independent variables and the study outcome, logistic regression of the variables at each level of determination was performed using Pearson's chi-square test. 
For the association among the variables, Odds Ratio was used. The outliers were excluded and the multicollinearity test was evaluated according to the parameters of Tolerance and VIF (Variance Inflation Factors).

The variables that were statistically significant in the univariate analysis $(p<0.20)$ were selected for multivariate analysis using the non-conditional forward stepwise (likelihood ratio) method.

For all inferential statistical tests, the significance level $p<0.05$ and the $R$ values 2 of Nagelkerke were used. The quality of fit was assessed by the Hosmer-Lemeshow test. To verify the normality of the data, the Kolmogorov-Smirnov test was used.

Participants signed a two-way Free Informed Consent Form (FICF). The project to which the present study is linked was approved by the Research Ethics Committee of the Hospital de Clinicas de Porto Alegre, under opinion No. 1,569,774/2016 and CAAE 55433516.1.0000.5327 on $6 / 1 / 2016$.

\section{RESULTS}

The study included 150 mothers and children for follow-up within 30 days postpartum. Total losses during follow-up were 29, 10 at 15 days and 19 at 30 days. At the end of the follow-up, $52.5 \%$ of the individuals were on EBF and 13 children had been weaned, three before the first 15 days.

Regarding the profile of the individuals studied, the characteristics of the sample are shown in Table 1.

Table 1 - Characteristics of mothers in rooming-in attended by BF consultants. Porto Alegre, RS, Brazil, 2016/2017

Variables

Maternal age $\geq 20$ years old

Maternal schooling $\geq 8$ years

Self-reported Caucasian mother

Having a partner

Performed prenatal care

No. of prenatal consultations $\geq 8^{\ddagger}$

148

122

$(81.3 \%)$

121

$(80.7 \%)$

93

$(62.0 \%)$

130

(86.7\%)

$(98.7 \%)$

Oriented on BF in prenatal careł

44

(29.7\%)

Smoking during pregnancy
Drug use during pregnancy

\begin{tabular}{lcc}
\hline Vaginal delivery & 88 & (58.7\%) \\
\hline
\end{tabular}

Family income (minimum wages) ${ }^{\#}$

2.2

$(1.3-3.4)^{*}$

Time of BF in previous child (months)" 3

$(0-11)^{*}$ 
Table 2 - Comparison between study variables and postpartum follow-up. Porto Alegre, RS, Brazil, 2016/2017

\begin{tabular}{|c|c|c|c|}
\hline \multirow{2}{*}{ Variables } & 15 days & 30 days & p-value \\
\hline & n (\%) & n (\%) & \\
\hline Exclusive breastfeeding & $96(64)$ & $62(41.3)$ & 0.000 \\
\hline Cross-breastfeeding & $4(2.7)$ & $9(6)$ & 0.063 \\
\hline Domestic and NB assistance & $124(82.7)$ & $97(64.7)$ & 0.115 \\
\hline Nipple/Nursing bottle use & $74(49.3)$ & $71(47.3)$ & 0.019 \\
\hline Cup/Spoon use & $8(5.3)$ & $5(3.3)$ & 0.125 \\
\hline Breast pain & $75(50)$ & $44(29.3)$ & 0.018 \\
\hline Breast cracks & $65(43.3)$ & $22(14.7)$ & 0.000 \\
\hline Full breast & $91(60.7)$ & $56(37.3)$ & 0.008 \\
\hline Breast erythema & $23(15.3)$ & $15(10)$ & 0.503 \\
\hline Breast fever & $14(9.3)$ & $13(8.7)$ & 0.832 \\
\hline Nipple anatomy & $11(7.3)$ & $5(3.3)$ & 0.289 \\
\hline Difficulty in the technique & $20(13.3)$ & $14(9.3)$ & 0.791 \\
\hline Low production & $11(7.3)$ & $9(6)$ & 0.754 \\
\hline Looking for professional help in BF & $24(16)$ & $10(6.7)$ & 0.064 \\
\hline
\end{tabular}

Source: Research data, 2016/2017.

The comparison between follow-up variables 15 and 30 days after delivery is described in Table 2.

The proportion of EBF maintenance was lower at 30 days postpartum compared to the first fifteen initial days, and this difference was significant. On the other hand, there was a significant reduction in the proportion of nipple/nursing bottle use, breast pain, cracks and full breasts.

The factors associated with EBF according to demographic, economic and reproductive characteristics are described in Table 3. In this first analysis, the type of delivery and prenatal guidance on BF were associated with the outcome of the study.
Table 4 shows the factors associated with EBF according to maternal habits related to breastfeeding. Not using a nipple/nursing bottle and not presenting cracks, as well as the use of a cup/ spoon and seeking professional help in BF were associated with the outcome.

Table 5 shows the final logistic regression of the significant variables. Having a normal delivery had a 4.18 times greater chance of sustaining EBF at the end of 30 days postpartum compared to women who had cesarean deliveries. Similarly, not using a nipple/ nursing bottle in this study presented a 23.08-fold chance of EBF maintenance. Finally, seeking professional help with BF after discharge acted as a protective factor for maintaining EBF. 
Table 3 - Univariate analysis of factors associated with EBF according to sociodemographic, economic and reproductive factors. Porto Alegre, RS, Brazil, 2016/2017

\begin{tabular}{|c|c|c|c|c|}
\hline & & ve breast & & \\
\hline Variables & $\begin{array}{c}\text { Yes } \\
(n=62)\end{array}$ & $\begin{array}{c}\text { No } \\
(n=46)\end{array}$ & $\begin{array}{c}\text { OR } \\
\text { (gross) }\end{array}$ & p-value \\
\hline Age group & & & & \\
\hline$\geq 20$ years old & $51(47.2)$ & $37(34.3)$ & 1 & 0.501 \\
\hline$<20$ years old & $11(10.2)$ & $9(8.3)$ & 1.12 & \\
\hline Parity & & & & 0.232 \\
\hline Primiparous & $36(33.6)$ & $23(21.5)$ & 0.69 & \\
\hline Multiparous & $25(23.4)$ & $23(21.5)$ & 1 & \\
\hline Income & & & & 0.252 \\
\hline$\geq 4$ wages & $10(10.9)$ & $5(5.4)$ & 1 & \\
\hline$<4$ wages & $41(44.6)$ & $36(39.1)$ & 1.75 & \\
\hline Schooling (years) & & & & 0.583 \\
\hline$\geq 8$ years old & $50(46.3)$ & $37(34.3)$ & 1 & \\
\hline$<8$ years & $12(11.1)$ & $9(8.3)$ & 1.10 & \\
\hline Type of delivery & & & & 0.044 \\
\hline Vaginal & $41(38)$ & $22(20.4)$ & 0.47 & \\
\hline Cesarean section & $21(19.4)$ & $24(22.2)$ & 1 & \\
\hline Episiotomy & & & & 0.108 \\
\hline Yes & $26(41.3)$ & $18(28.6)$ & 1 & \\
\hline No & $15(23.8)$ & $4(6.3)$ & 0.38 & \\
\hline Cohabitation partner & & & & 0.520 \\
\hline Yes & $49(51)$ & $39(40.6)$ & 0.79 & \\
\hline No & $4(4.2)$ & $4(4.2)$ & 1 & \\
\hline Smoking & & & & 0.504 \\
\hline Yes & $7(6.5)$ & $6(5.6)$ & & \\
\hline No & $55(50.9)$ & $40(37)$ & & \\
\hline No. of prenatal consultations & & & & 0.395 \\
\hline$>8$ consultations & 49 (47.6) & $32(31.1)$ & 1 & \\
\hline$\leq 8$ consultations & $11(12.7)$ & $10(9.7)$ & 1.27 & \\
\hline PN guidance on BF & & & & 0.023 \\
\hline Yes & $24(22.4)$ & $9(8.4)$ & 1 & \\
\hline No & $37(34.6)$ & $37(34.6)$ & 2.66 & \\
\hline $\begin{array}{l}\text { Previous history of failure } \\
\text { with BF }\end{array}$ & & & & 0.613 \\
\hline Yes & $53(49.5)$ & $40(37.4)$ & 1.10 & \\
\hline No & $8(7.5)$ & $6(5.6)$ & 1 & \\
\hline
\end{tabular}

Source: Research data, 2016/2017. 
Gasparin VA, Strada JKR, Moraes BA, Betti T, Pitilin EB, Espírito Santo LC

Table 4 - Univariate analysis of factors associated with EBF according to maternal habits related to breastfeeding. Porto Alegre, RS, Brazil, 2016/2017

\begin{tabular}{|c|c|c|c|c|}
\hline \multirow{2}{*}{ Variables } & \multicolumn{3}{|c|}{ Exclusive breastfeeding } & \multirow[b]{2}{*}{ p-value } \\
\hline & $\begin{array}{c}\text { Yes } \\
(n=62)\end{array}$ & $\begin{array}{c}\text { No } \\
(n=46)\end{array}$ & $\begin{array}{c}\text { OR } \\
\text { (gross) }\end{array}$ & \\
\hline Nipple/Nursing bottle use & & & & 0.000 \\
\hline Yes & $20(18.5)$ & $41(38)$ & 17.22 & \\
\hline No & $42(38.9)$ & $5(4.6)$ & 1 & \\
\hline Breast pain & & & & 0.207 \\
\hline Yes & $21(19.4)$ & $20(18.5)$ & 1.50 & \\
\hline No & $41(38)$ & $26(24.1)$ & 1 & \\
\hline Breast cracks & & & & 0.023 \\
\hline Yes & $8(7.4)$ & $14(13)$ & 2.95 & \\
\hline No & $54(50)$ & $32(29.6)$ & 1 & \\
\hline Full breast & & & & 0.555 \\
\hline Yes & $30(27.8)$ & $22(20.4)$ & 1 & \\
\hline No & $32(29.6)$ & $34(22.2)$ & 0.97 & \\
\hline Difficulty in the technique & & & & 0.202 \\
\hline Yes & $4(3.7)$ & $6(5.6)$ & 2.17 & \\
\hline No & $58(53.7)$ & $40(37)$ & 1 & \\
\hline Nipple anatomy & & & & 0.389 \\
\hline Yes & $1(0.9)$ & $2(1.9)$ & 2.77 & \\
\hline No & $61(56.5)$ & $44(40.7)$ & 1 & \\
\hline Cup/Spoon use & & & & 0.000 \\
\hline Yes & $24(22.2)$ & $4(3.7)$ & 1 & \\
\hline No & $38(35.2)$ & $42(38.9)$ & 6.63 & \\
\hline Domestic and NB assistance & & & & 0.417 \\
\hline Yes & $49(45.4)$ & $38(35.2)$ & 0.79 & \\
\hline No & $13(12)$ & $8(7.4)$ & 1 & \\
\hline $\begin{array}{l}\text { Seeking professional help in BF } \\
\text { after discharge }\end{array}$ & & & & 0.010 \\
\hline Yes & $1(0.9)$ & $7(6.5)$ & 1 & \\
\hline No & $61(56.5)$ & $39(36.1)$ & 10.94 & \\
\hline
\end{tabular}

Source: Research data, 2016/2017. 
Table 5 - Final multivariate logistic regression of factors associated with EBF. Porto Alegre, RS, Brazil, 2016/2017

\begin{tabular}{|c|c|c|c|}
\hline Variables & Adjusted OR & $\mathrm{Cl} 95 \%$ & p-value \\
\hline Nipple/Nursing bottle use & 23.08 & $5.86-90.92$ & 0.000 \\
\hline Cup/Spoon use & 1.74 & $0.40-7.53$ & 0.457 \\
\hline Breast cracks & 1.03 & $0.26-4.05$ & 0.963 \\
\hline Seeking professional help in BF after discharge & 0.05 & $0.00-0.92$ & 0.044 \\
\hline PN guidance on BF & 0.56 & $0.17-1.87$ & 0.353 \\
\hline Type of delivery & 4.18 & $1.27-13.71$ & 0.018 \\
\hline
\end{tabular}

Source: Research data, 2016/2017.

\section{DISCUSSION}

The data showed that the maintenance of EBF occurred in more than half of the subjects studied. A research conducted in Ceará found lower results in the same period $(39.2 \%)^{(10)}$. It can be inferred from this that, although the subjects studied present some previous difficulty related to BF, the support offered by breastfeeding consultancy acted in solving this demand, increasing the proportion of mothers and children in EBF. A quasi-experiment conducted in the Netherlands corroborates the assertion that the intervention by individuals trained by the IBCLC is effective in increasing the duration and exclusivity of breastfeeding, as well as in delaying weaning ${ }^{(5)}$.

The introduction of water was justified by the mothers by the feeling that the child was feeling thirsty. However, many mothers are unaware of the high presence of water contained in the socalled previous milk, which is offered at the beginning of breastfeeding ${ }^{(11)}$; this makes the offer of liquid to the child completely independent of the seasonal period.

Most of the times, tea was introduced in an attempt to calm the child's colic. A study conducted in Maranhão also demonstrated the use of tea for the same purpose ${ }^{(12)}$.

The introduction of breast milk substitutes was justified by the fact that the child cries from hunger, associating to this the perception of breast milk being weak. A study conducted in São Paulo was in line with this finding, since $47 \%$ of the participants believe they have weak milk, motivated by the child's crying ${ }^{(13)}$.

The mothers who introduced some liquid to their children did so with the aid of a nursing bottle in most cases. The harm associated with the use of a nursing bottle and a pacifier regarding the maintenance of EBF has already been described at national(14) and international(15) levels. In this research, the non-use of such artifacts presented a 23.08 times greater chance of maintaining EBF. Early introduction of artificial nipples, such as a pacifier and a nursing bottle, can contribute to the confusion of nipples by the child, also affecting grip and sucking, determining factors for successful breastfeeding ${ }^{(14)}$.

Having a normal delivery had a 4.18 times greater chance of sustaining EBF at the end of 30 days postpartum compared to women who had cesarean deliveries. The mode of delivery is related to the early onset of breastfeeding, as it should occur immediately after birth, as recommended by Step 4 of the Baby Friendly Hospital Initiative, in order, among other reasons, to foster bonding, increasing the duration of breastfeeding ${ }^{(14)}$. A survey conducted in Saudi Arabia found that mothers who had a cesarean delivery were about 1.42 times more likely not to breastfeed in the first hour of life when compared to mothers who had a vaginal delivery ${ }^{(16)}$.

The search for a professional for breastfeeding assistance after discharge acted as a protective factor for the maintenance of EBF. A study conducted in Turkey was in line with this result ${ }^{(15)}$. Late postpartum is sometimes less evidenced, taking into account the actions to strengthen $\mathrm{BF}$ in the prenatal and in the immediate postpartum. However, it is considered a vulnerable period, and research has already pointed to the need for continued breastfeeding care and counseling ${ }^{(17-18)}$.

Accordingly, the Ministry of Health has implemented the First Week Integral Health as a strategy, an action that aims to provide integral and multi-professional care to the postpartum woman and to the child in the first week after delivery. It can be performed through home visits aimed at identifying risk signs, providing guidance and encouraging BF. This strategy has great potential in improving the quality of life of the mother and of the child, it assists in maternal empowerment and delays the introduction of breast milk substitutes ${ }^{(19)}$.

It is noteworthy that, despite the BF advice offered during hospitalization, the subjects referred to this service already had some degree of difficulty with BF, needing more attention and supporting the search for help also after hospital discharge which, according to the findings of this study, seems to favor EBF. 


\section{口 CONCLUSION}

Vaginal delivery, not using a pacifier or a nursing bottle and seeking professional help after discharge were associated with the maintenance of EBF in the late postpartum. The alleged reasons for introducing water, tea, and breast milk substitutes were thirst, abdominal cramps, and infant crying, respectively. Such reasons, although already described in other studies, do not represent situations in which there is a concrete indication of the introduction of such liquids.

Despite the assumption that institutions accredited as Child Friendly have professionals engaged in the cause of $\mathrm{BF}$, the insertion of a professional breastfeeding consultant who acts exclusively in response to this demand is of significant importance, especially regarding the rise in EBF rates, providing the proven benefits of breastfeeding to the subjects involved.

Further studies are suggested, especially at the national level, which cover the performance of this professional and the relevance of their inclusion in the team, providing greater visibility and instigating future investments of the part of health services to enjoy the benefits provided by their work.

\section{口 REFERENCES}

1. CavalcantiSH, CaminhaMFC, Figueiroa IN, ServaVMSBD, CruzRSBLC, LiraPIC, etal. Factors associated with breasffeeding practice for at least six months in the state of Pernambuco, Brazil. Rev Bras Epidemiol. 2015;18(1):208-19. doi: https://doi.org/10.1590/19805497201500010016

2. Victora $\mathrm{CG}$, Bahl R, Barros AJD, França GVA, Horton S, Krasevec J, et al. Breastfeeding in the 21st century: epidemiology, mechanisms, and lifelong effect. The Lancet. 2016;387(10017):475-90. doi: https://doi.org/10.1016/50140-6736(15)01024-7

3. Haase B, Brennan E, Wagner CL. Effectiveness of the IBCLC: have we made an impact on the care of breastfeeding families over the past decade?.J Hum Lact. 2019;35(3):441-52. doi: https://doi.org/10.1177/0890334419851805

4. Chiurco A,Montico M, Brovedani P,Monasta L, Davanzo R. An IBCLC in the maternity ward of a mother and child hospital: a pre-and post-intervention study. Int J Environ Res Public Health. 2015;12(8):9938-51. doi: https://doi.org/10.3390/ijerph120809938

5. van Dellen SA, Wisse B, Mobach MP, Dijkstra A. The effect of a breastfeeding support programme on breastfeeding duration and exclusivity: a quasi-experiment. BMC Public Health. 2019;19:993. doi: https://doi.org/10.1186/s12889-019-7331-y

6. Chetwynd EM, Wasser HM, PooleC. Breastfeeding support interventions by International Board Certified Lactation Consultants: a systemic review and meta-analysis. J Hum Lact. 2019;35(3):424-40. doi: https://doi.org/10.1177/0890334419851482

7. Oliveira CS, locca FA, Carrijo MLR, Garcia RATM. Breasffeeding and complications that contribute to early weaning. Rev Gaúcha Enferm. 2015;36(esp):16-23. doi: https://doi. org/10.1590/1983-1447.2015.esp.56766

\section{Corresponding author:}

Vanessa Aparecida Gasparin

E-mail: vane-gasparin@hotmail.com
8. Ministry of Health (BR). Secretaria de Atenção à Saúde. Departamento de Açōes Programáticas e Estratégicas. II Pesquisa de Prevalência de Aleitamento Materno nas Capitais Brasileiras e Distrito Federal. Brasilia: Ministério da Saúde; 2009 [cited 2019 Feb 25]. Available from: http://busms.saude.gov.br/bvs/publicacoes/pesquisa_ prevalencia_aleitamento_materno.pdf

9. Giugliani ER, Espirito Santo LC, Oliveira LD, Aerts D. Intake of water, herbal teas and nonbreast milks during the first month of life: associated factors and impact on breastfeeding duration. Early Hum Dev. 2008;84(5):305-10. doi: https://doi.org/10.1016/j. earthumdev.2007.08.001

10. Ferreira HLOC, Oliveira MF, Bemardo EBR, Almeida PC, Aquino PS, Pinheiro AKB. Factors associated with adherence to the exclusive breasffeeding. Cienc Saúde Coletiva. 2018;23(3):683-90. doi: https://doi.org/10.1590/1413-81232018233.06262016

11. Ministry of Heatth (BR). Secretaria de Atençãoa Saúde. Departamento de Atenção Básica. Saúde da criança: aleitamento materno e alimentação complementar. Brasilia:Ministério da Saúde; 2015 [cited 2017 Apr 30]. Available from: http://bvsms.saude.gov.br/bvs/ publicacoes/saude_crianca_aleitamento_materno_cab23.pdf

12. Pereira de Jesus AC, Bandeira LPL, Araújo MFM, Gubert FA, Vieira NFC, Rebouças CBA. Popular knowledge in care of the newborn with focus on health promotion. Rev. Pesqui Cuid Fundam (Online). 2013;5(2):3626-35. doi: https://doi.org/10.9789/21755361.2013.v5i2.3626-3635

13. Simões IAR, RennóG, Salomon ASC, Martins MCM, DeSáRAD. Influência dos mitos edas crenças nas nutrizes quanto amamentação em uma cidade do Vale do Parabba. Rev Ciênc Saúde. 2015 [cited 2017 Nov 12];5(3):1-9. Available from: http://rss.fmitedu.br/index. php/rssfmit_zero/article/view/385/pdf

14. Santos EM, Silva LS, Rodrigues BFS, Amorim TMAX, Silva CS, Borba JMC, et al. Breastfeeding assessment in children up to 2 years of age assisted in primary heatth care of Recife in the state of Pernambuco, Brazil. Cienc Saúde Coletiva. 2019;24(3):1211-22. doi: https://doi.org/10.1590/1413-81232018243.12612017

15. Salcan S, Topal I, Ates I. The frequency and effective factors of exclusive breastfeeding for the first six months in babies borm in Erzincan Province in 2016. Eurasian J Med. 2019;51(2):145-9. doi: https://doi.org/10.5152/eurasianjmed.2018.18310

16. Azzeh FS, Alazzeh AY, Hijazi HH, Wazzan HY, Jawharij MT, Jazar AS, etal. Factors associated with not breastfeeding and delaying the early initiation of breastfeeding in Mecca Region, Saudi Arabia. Children. 2018:5(1):8. doi: https://doi.org/10.3390/children5010008

17. Doherty T, Horwood C, Haskins L, Magasana V, Goga A, Feucht U, et al. Breastfeeding advice for reality: women's perspectives on infant feeding support received in primary health care settings in South Africa. Matem Child Nutr. 2019;24:e12877. doi: https://doi. org/10.1111/mcn.12877

18. Hamze L, Mao J, Reifsnider E. Knowledge and attitudes towards breastfeeding practices: a cross-sectional survey of postnatal mothers in China. Midwifery. 2019;74:68-75. doi: https://doi.org/10.1016/.jmidw.2019.03.009

19. Lucena DBA, Guedes ATA, CruzTMAV, Santos NCCB, Collet N, Reichert APS. First week of integral health for thenewborn: nursing actions of the Family Health Strategy. Rev Gaúcha Enferm. 2018;39:22017-0068. doi: https://doi.org/10.1590/1983-1447.2018.20170068

ACKNOWLEDGMENTS: To the nurses Cléa Machado de Carvalho and Marcia Knoener, who enabled this research through the work done in the breastfeeding consultancy.

Received: 03.06.2019

Approved: 08.13.2019 